\title{
Diagnosis, Therapy and Follow-up Care of Vulvar Cancer and its Precursors. Guideline of the DGGG and DKG (S2k-Level, AWMF Registry Number 015/059, November 2015
}

\author{
Diagnostik, Therapie und Nachsorge des Vulvakarzinoms und seiner Vorstufen. \\ Leitlinie der DGGG und DKG (S2k-Level, AWMF-Registernummer 015/059, November 2015)
}

Authors

Affiliations
H. G. Schnürch ${ }^{1}$, S. Ackermann ${ }^{2}$, C. D. Alt ${ }^{3}$, J. Barinoff ${ }^{4}$, C. Böing ${ }^{5}$, C. Dannecker ${ }^{6}$, F. Gieseking ${ }^{7}$, A. Günthert ${ }^{8}$, P. Hantschmann ${ }^{9}$, L. C. Horn ${ }^{10}$, R. Kürzl ${ }^{11}$, P. Mallmann ${ }^{12}$, S. Marnitz ${ }^{13}$, G. Mehlhorn ${ }^{14}$, C. C. Hack ${ }^{14}$, M. C. Koch ${ }^{14}$, U. Torsten ${ }^{15}$, W. Weikel ${ }^{16}$, L. Wölber ${ }^{17}$, M. Hampl ${ }^{18}$

The affiliations are listed at the end of the article.

Key words
vulvar cancer
diagnosis
therapy
vulvar intraepithelial
neoplasia

Schlüsselwörter

- Vulvakarzinom

- Diagnostik

- Therapie

- VIN

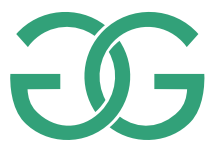

OEGGG

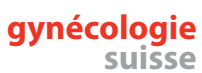

Deutsche Version unter: http://dx.doi.org/ 10.1055/s-0042-103728

Bïliography DOI http://dx.doi.org/ 10.1055/s-0042-103728 Geburtsh Frauenheilk 2016; 76: 1035-1049 ๑ Georg Thieme Verlag KG Stuttgart · New York . ISSN 0016-5751

\section{Correspondence}

Prof. Dr. Hans-Georg Schnürch Ehemaliger Chefarz der Frauenklinik am Lukaskrankenhaus Neuss Im Hunengraben 9 41564 Kaarst

hschnuerch@t-online.de

\section{Abstract}

$\nabla$

Purpose: This is an official guideline, published and coordinated by the Arbeitsgemeinschaft Gynäkologische Onkologie (AGO, Study Group for Gynecologic Oncology) of the Deutsche Krebsgesellschaft (DKG, German Cancer Society) and the Deutsche Gesellschaft für Gynäkologie und Geburtshilfe (DGGG, German Society for Gynecology and Obstetrics). The number of cases with vulvar cancer is on the rise, but because of the former rarity of this condition and the resulting lack of literature with a high level of evidence, in many areas knowledge of the optimal clinical management still lags behind what would be required. This updated guideline aims to disseminate the most recent recommendations, which are much clearer and more individualized, and is intended to create a basis for the assessment and improvement of quality care in hospitals.

Methods: This S2k guideline was drafted by members of the AGO Committee on Vulvar and Vaginal Tumors; it was developed and formally completed in accordance with the structured consensus process of the Association of Scientific Medical Societies in Germany (Arbeitsgemeinschaft der Wissenschaftlichen Medizinischen Fachgesellschaften, AWMF).

Recommendations: 1 . The incidence of disease must be taken into consideration. 2 . The diagnostic pathway, which is determined by the initial findings, must be followed. 3. The clinical and therapeutic management of vulvar cancer must be done on an individual basis and depends on the stage of disease. 4 . The indications for sentinel lymph node biopsy must be evaluated very carefully. 5. Follow-up and treatment for recurrence must be adapted to the individual case.

\section{Zusammenfassung \\ $\nabla$}

Ziel: Offizielle Leitlinie, publiziert und koordiniert von der Arbeitsgemeinschaft Gynäkologische Onkologie (AGO) in der Deutschen Krebsgesellschaft (DKG) und der Deutschen Gesellschaft für Gynäkologie und Geburtshilfe (DGGG). Vulvakarzinome nehmen an Anzahl stetig zu, während die Kenntnisse über das optimale klinische Management wegen der früheren Seltenheit und dem daraus resultierenden Mangel an Literatur-Evidenz dem Bedarf an vielen Stellen noch hinterherhinken. Dieses Leitlinien-Update soll die aktuell deutlich klareren und individualisierten Behandlungsempfehlungen möglichst weit verbreiten und die Grundlage für eine Qualitätsmessung und Qualitätssteigerung in Kliniken bieten.

Methoden: Die vorliegende S2k-Leitlinie wurde von den Mitgliedern der Kommission Vulva- und Vaginaltumoren der AGO entworfen und in einem methodisch überwachten Konsensusverfahren der Arbeitsgemeinschaft der Wissenschaftlichen Medizinischen Fachgesellschaften (AWMF) strukturiert entwickelt und formal abgeschlossen.

Empfehlungen: 1. Beachtung der Inzidenz. 2. Einhaltung der abgestuften Diagnostik in Abhängigkeit vom Ausgangsstadium. 3. Individualisiertes klinisch-therapeutisches Management der Vulvakarzinome in Abhängigkeit vom Stadium. 4. Ausgewogene Indikationsstellung zur SentinelLymphknoten-Biopsie. 5. Adaptierte Nachsorge und Behandlung im Rezidivfall. 


\section{Information on the Guideline}

Guidelines program of the DGGG, OEGGG and SGGG Information on the guidelines program is available at the end of the guideline.

\section{Citation format}

Diagnosis, Therapy, and Follow-Up Care of Vulvar Cancer and its Precursors. Guideline of the DGGG and DKG (S2k-Level, AWMF Registry No. 015/059, November 2015). Geburtsh Frauenheilk 2016; 76: 1035-1049

\section{Guideline documents}

The complete long version of this guideline with a summary of the conflicts of interest of all authors, a short version and a PDF slide version for PowerPoint is available in German on the homepage of the AWMF:

http://www.awmf.org/leitlinien/detail/11/015-059.html

\section{Numbering}

This text is a condensed version which has omitted chapters on more generalized issues. Nevertheless, to make it easier to find the respective passages in the long version, the numbering of chapters and tables and figures in "IV - Guideline" and the numbering of the recommendations and statements corresponds to the numbering used in the long version.

\section{Authors}

See $\boldsymbol{O}$ Table 1.

\section{Abbreviations}

AGO Study Group for Gynecologic Oncology

(Arbeitsgemeinschaft Gynäkologische Onkologie)

AWMF Association of the Scientific Medical Societies in Germany (Arbeitsgemeinschaft der Wissenschaftlichen Medizinischen Fachgesellschaften)

CT computed tomography

DKG German Cancer Society (Deutsche Krebs Gesellschaft)

DGGG German Society for Gynecology and Obstetrics

(Deutsche Gesellschaft für Gynäkologie und Geburtshilfe)

dVIN differentiated vulvar intraepithelial neoplasia

EC expert consensus

FDG fluorodeoxyglucose

FDG-PET fluorodeoxyglucose positron emission tomography

Gy gray

HIV human immunodeficiency virus

HPV human papillomavirus

HSIL high-grade squamous intraepithelial lesion

IMRT intensity-modulated radiation therapy

ISSVD International Society for the Study of Vulvo-vaginal Disease

Laser light amplification by stimulated emission of radiation

LD max. longitudinal diameter

LN lymph nodes

LND lymphadenectomy

L-status extent of lymphatic vessel infiltration

in pTNM staging
LSIL low-grade squamous intraepithelial lesion

MRI magnetic resonance imaging

p53 53-kilodalton tumor suppressor protein

PET-CT positron emission tomography-computed tomography

Pn-status extent of perineural sheath infiltration

in pTNM staging

pTNM pathologic TNM staging

R1 microscopic evidence of tumor

R2 macroscopic evidence of tumor

RKI Robert Koch Institute

R-status extent of residual tumor using the

pTNM tumor classification system

TD max. transverse diameter

TNM UICC staging system for malignant tumors

UICC Union international contre le cancer

uVIN classic or usual vulvar intraepithelial neoplasia

VAIN vaginal intraepithelial neoplasia

VIN vulvar intraepithelial neoplasia

V-status invasion of veins in pTNM staging

\section{Application of the Guideline}

\section{Purpose and objectives}

The purpose of this guideline is to optimize the management of patients with vulvar cancer by describing and summarizing current medical standards. The recommendations developed and described in this guideline are intended as a basis for quality management in oncology. The quality indicators (listed in both the long and the short version) derived from this guideline can be used for the purpose of scientific quality control and to certify treatment centers. The aim is to maintain and improve the quality of the oncological care available in Germany based on scientifically verified recommendations.

\section{Targeted areas of patient care}

The guideline provides information on the characteristics of vulvar cancer and the optimal diagnostic work-up and treatment. It should serve as the basis for a discussion of individual treatment plans by an interdisciplinary board. The clinical information has been incorporated into comments on the most important psychosocial events, the various rehabilitation strategies and the most suitable follow-up care for patients with this neoplasm.

\section{Target audience}

This S2k guideline targets all physicians and professionals involved in the outpatient and/or inpatient care of patients with vulvar cancer. This guideline can additionally serve as an important source of information for affected patients and their relatives.

\section{Period of validity}

The validity of this guideline was confirmed in December 2015 by the respective committees of the DKG and the DGGG and will remain valid until December 2020. If there should be important changes to the available evidence, then amendments to the guideline can be published prior to its expiry date after a careful review of the new evidence in accordance with the methodology published by the AWMF. 
Table 1 Authors.

\begin{tabular}{|c|c|}
\hline $\begin{array}{l}\text { Author } \\
\text { Mandate holder }\end{array}$ & DGGG working group/medical society/organization/association \\
\hline \multicolumn{2}{|l|}{$\begin{array}{l}\text { Mandate holder } \\
\text { Coordinating lead guideline authors: }\end{array}$} \\
\hline Prof. Dr. med. Hans-Georg Schnürch & $\begin{array}{l}\text { German Society of Gynecology and Obstetrics (Deutsche Gesellschaft für Gynäkologie und Geburtshilfe e.V. [DGGG]), } \\
\text { German Cancer Society (Deutsche Krebsgesellschaft e. V. [DKG]), } \\
\text { Gynecological Oncology Working Group (Arbeitsgemeinschaft Gynäkologische Onkologie [AGO]) }\end{array}$ \\
\hline Prof. Dr. med. Monika Hampl & $\begin{array}{l}\text { German Society of Gynecology and Obstetrics (Deutsche Gesellschaft für Gynäkologie und Geburtshilfe e.V. [DGGG]), } \\
\text { German Cancer Society (Deutsche Krebsgesellschaft e.V. [DKG]), } \\
\text { Gynecological Oncology Working Group (Arbeitsgemeinschaft Gynäkologische Onkologie [AGO]) }\end{array}$ \\
\hline \multicolumn{2}{|l|}{ Other lead guideline authors: } \\
\hline PD Dr. med. Sven Ackermann & $\begin{array}{l}\text { German Society of Gynecology and Obstetrics (Deutsche Gesellschaft für Gynäkologie und Geburtshilfe e.V. [DGGG]), } \\
\text { German Cancer Society (Deutsche Krebsgesellschaft e. V. [DKG]), } \\
\text { Gynecological Oncology Working Group (Arbeitsgemeinschaft Gynäkologische Onkologie [AGO]) }\end{array}$ \\
\hline Dr. med. Celine Desiree Alt & German Radiological Society (Deutsche Röntgengesellschaft e. V. [DRG]), Uroradiology Working Group (AG Uroradiologie) \\
\hline Dr. med. Jana Barinoff & $\begin{array}{l}\text { German Society of Gynecology and Obstetrics (Deutsche Gesellschaft für Gynäkologie und Geburtshilfe e. V. [DGGG]), } \\
\text { German Cancer Society (Deutsche Krebsgesellschaft e. V. [DKG]), } \\
\text { Gynecological Oncology Working Group (Arbeitsgemeinschaft Gynäkologische Onkologie [AGO]) }\end{array}$ \\
\hline Christiane Böhlke & Vulvar Cancer Self-help Group (VulvaKarzinom-SHG e.V.) \\
\hline Dr. med. Carsten Böing & $\begin{array}{l}\text { German Society of Gynecology and Obstetrics (Deutsche Gesellschaft für Gynäkologie und Geburtshilfe e. V. [DGGG]), } \\
\text { German Cancer Society (Deutsche Krebsgesellschaft e.V. [DKG]), } \\
\text { Gynecological Oncology Working Group (Arbeitsgemeinschaft Gynäkologische Onkologie [AGO]) }\end{array}$ \\
\hline Prof. Dr. med. Christian Dannecker & $\begin{array}{l}\text { German Society of Gynecology and Obstetrics (Deutsche Gesellschaft für Gynäkologie und Geburtshilfe e. V. [DGGG]), } \\
\text { German Cancer Society (Deutsche Krebsgesellschaft e.V. [DKG]), } \\
\text { Gynecological Oncology Working Group (Arbeitsgemeinschaft Gynäkologische Onkologie [AGO]) }\end{array}$ \\
\hline Dr. med. Friederike Gieseking & $\begin{array}{l}\text { German Society of Gynecology and Obstetrics (Deutsche Gesellschaft für Gynäkologie und Geburtshilfe e. V. [DGGG]), } \\
\text { German Cancer Society (Deutsche Krebsgesellschaft e.V. [DKG]), } \\
\text { Gynecological Oncology Working Group (Arbeitsgemeinschaft Gynäkologische Onkologie [AGO]) }\end{array}$ \\
\hline Prof. Dr. med. Andreas Günthert & $\begin{array}{l}\text { German Society of Gynecology and Obstetrics (Deutsche Gesellschaft für Gynäkologie und Geburtshilfe e. V. [DGGG]), } \\
\text { German Cancer Society (Deutsche Krebsgesellschaft e.V. [DKG]), } \\
\text { Gynecological Oncology Working Group (Arbeitsgemeinschaft Gynäkologische Onkologie [AGO]) }\end{array}$ \\
\hline Dr. med. Carolin C. Hack & $\begin{array}{l}\text { German Society of Gynecology and Obstetrics (Deutsche Gesellschaft für Gynäkologie und Geburtshilfe e.V. [DGGG]), } \\
\text { German Cancer Society (Deutsche Krebsgesellschaft e.V. [DKG]), } \\
\text { Gynecological Oncology Working Group (Arbeitsgemeinschaft Gynäkologische Onkologie [AGO]) }\end{array}$ \\
\hline Dr. med. Peer Hantschmann & $\begin{array}{l}\text { German Society of Gynecology and Obstetrics (Deutsche Gesellschaft für Gynäkologie und Geburtshilfe e. V. [DGGG]), } \\
\text { German Cancer Society (Deutsche Krebsgesellschaft e.V. [DKG]), } \\
\text { Gynecological Oncology Working Group (Arbeitsgemeinschaft Gynäkologische Onkologie [AGO]) }\end{array}$ \\
\hline Prof. Dr. med. Lars Christian Horn & $\begin{array}{l}\text { German Pathology Society (Deutsche Gesellschaft für Pathologie e. V. [DGP]), } \\
\text { Gynecological Oncology Working Group (Arbeitsgemeinschaft Gynäkologische Onkologie [AGO]) }\end{array}$ \\
\hline Dr. med. Martin C. Koch & $\begin{array}{l}\text { German Society of Gynecology and Obstetrics (Deutsche Gesellschaft für Gynäkologie und Geburtshilfe e.V. [DGGG]), } \\
\text { German Cancer Society (Deutsche Krebsgesellschaft e.V. [DKG]), } \\
\text { Gynecological Oncology Working Group (Arbeitsgemeinschaft Gynäkologische Onkologie [AGO]) }\end{array}$ \\
\hline Prof. Dr. med. Rainer Kürzl & $\begin{array}{l}\text { German Society of Gynecology and Obstetrics (Deutsche Gesellschaft für Gynäkologie und Geburtshilfe e.V. [DGGG]), } \\
\text { German Cancer Society (Deutsche Krebsgesellschaft e.V. [DKG]), } \\
\text { Gynecological Oncology Working Group (Arbeitsgemeinschaft Gynäkologische Onkologie [AGO]) }\end{array}$ \\
\hline Prof. Dr. med. Peter Mallmann & $\begin{array}{l}\text { German Society of Gynecology and Obstetrics (Deutsche Gesellschaft für Gynäkologie und Geburtshilfe e.V. [DGGG]), } \\
\text { German Cancer Society (Deutsche Krebsgesellschaft e.V. [DKG]), } \\
\text { Gynecological Oncology Working Group (Arbeitsgemeinschaft Gynäkologische Onkologie [AGO]) }\end{array}$ \\
\hline Prof. Dr. med. Simone Marnitz & $\begin{array}{l}\text { German Radio-oncology Society (Deutsche Gesellschaft für Radioonkologie e. V. [DEGRO]), } \\
\text { Gynecological Oncology Working Group (Arbeitsgemeinschaft Gynäkologische Onkologie [AGO]) }\end{array}$ \\
\hline PD Dr. med. Grit Mehlhorn & $\begin{array}{l}\text { German Society of Gynecology and Obstetrics (Deutsche Gesellschaft für Gynäkologie und Geburtshilfe e.V. [DGGG]), } \\
\text { German Cancer Society (Deutsche Krebsgesellschaft e.V. [DKG]), } \\
\text { Gynecological Oncology Working Group (Arbeitsgemeinschaft Gynäkologische Onkologie [AGO]) }\end{array}$ \\
\hline PD Dr. med. Uwe Torsten & $\begin{array}{l}\text { German Society of Gynecology and Obstetrics (Deutsche Gesellschaft für Gynäkologie und Geburtshilfe e. V. [DGGG]), } \\
\text { German Cancer Society (Deutsche Krebsgesellschaft e. V. [DKG]), } \\
\text { Gynecological Oncology Working Group (Arbeitsgemeinschaft Gynäkologische Onkologie [AGO]) }\end{array}$ \\
\hline Prof. Dr. med. Wolfgang Weikel & $\begin{array}{l}\text { German Society of Gynecology and Obstetrics (Deutsche Gesellschaft für Gynäkologie und Geburtshilfe e. V. [DGGG]), } \\
\text { German Cancer Society (Deutsche Krebsgesellschaft e.V. [DKG]), } \\
\text { Gynecological Oncology Working Group (Arbeitsgemeinschaft Gynäkologische Onkologie [AGO]) }\end{array}$ \\
\hline PD Dr. med. Linn Wölber & $\begin{array}{l}\text { German Society of Gynecology and Obstetrics (Deutsche Gesellschaft für Gynäkologie und Geburtshilfe e. V. [DGGG]), } \\
\text { German Cancer Society (Deutsche Krebsgesellschaft e.V. [DKG]), } \\
\text { Gynecological Oncology Working Group (Arbeitsgemeinschaft Gynäkologische Onkologie [AGO]) }\end{array}$ \\
\hline
\end{tabular}




\section{Methodology of the Guideline}

The methodology used to compile this guideline was based on a stratified classification system. The rules are prescribed by the AWMF rulebook (version 1.0). Guidelines are differentiated into lowest level (S1), intermediate level (S2) and highest level (S3). The lowest level is defined as a collection of recommendations for action compiled by a non-representative group of experts. In 2004 the S2 category was subdivided into 2 sublevels: systematic evidence-based (S2e) and structurally consensus-based (S2k). The highest level (S3) integrates both approaches.

\section{This guideline corresponds to the level: $\mathbf{S 2} \mathbf{k}$}

The text of the clinical guideline was drawn up and the statements/recommendations were developed by the members of the AGO Committee on Vulvar and Vaginal Tumors after a systematic literature search. The text and all statements/recommendations were jointly reviewed by all members of the committee. The accompanying chapters on psychosocial aspects were taken from other (S3) gynecologic oncology guidelines and adapted to take account of the specific issues of vulvar cancer. The highlighted statements and recommendations were agreed upon in a consensus conference after a structured process. The participants in the consensus conference consisted of mandate holders from involved and associated scientific medical societies and professional associations working alongside patients' representatives from various self-help groups. This guideline was confirmed in December 2015 by the Guideline Committee of the DGGG and the DKG. More details on the development and consensus process used for this guideline are available in the long version.

\section{Recommendations}

The individual recommendations have been formulated in such a way that they indicate the level of requirement for each recommendation. There are three levels of requirement. The level of requirement depends on the ratio between the benefits and the disadvantages of alternative approaches. The terms "must/must not" indicate a strong recommendation (high level of requirement), "should/should not" indicate a simple recommendation (mid-level requirement), and "can" or "may"/“cannot" or "may not" signify an open recommendation (limited level of requirement). The guidelines are not mandatory; they consist of recommendations compiled by a panel of experts, with different levels of requirement for each recommendation. In every individual clinical case, the physician must examine the relevance and appropriateness of the recommendation; if the recommendation is contraindicated, the physician must make a decision after carefully weighing up the options. This also applies to strong recommendations.

\section{Statements}

If statements by specialists are included in this guideline that are not intended as recommendations for action, but rather simply for the purpose of presentation, these are referred to as "statements". For these statements, it is not possible to indicate evidence levels.

\section{Consensus strength}

As part of a structured consensus agreement process (S2k/S3 level), the eligible participants at the meeting agree on the statements and recommendations that were drawn up. During this process, significant modifications to the wording may occur. Sub- sequently, the consensus strength is determined based on the number of participants ( 0 Table 2 ).

\section{Expert consensus}

Table 2 Classification of consensus strength.

\begin{tabular}{lll}
$\begin{array}{l}\text { Symbol } \\
+++\end{array}$ & $\begin{array}{l}\text { Consensus strength } \\
\text { Strong consensus }\end{array}$ & $\begin{array}{l}\text { Agreement in percent } \\
\text { Agreement of } \\
>95 \% \text { of the participants }\end{array}$ \\
\hline++ & Consensus & $\begin{array}{l}\text { Agreement of } \\
>75-95 \% \text { of the participants }\end{array}$ \\
\hline+ & Majority agreement & $\begin{array}{l}\text { Agreement of } \\
>50-75 \% \text { of the participants }\end{array}$ \\
\hline- & No consensus & $\begin{array}{l}\text { Agreement of } \\
<50 \% \text { of the participants }\end{array}$
\end{tabular}

As the name suggests, "expert consensus" refers to consensus decision specifically for recommendations/statements without a prior systematic literature search (S2k) or based on the missing evidence (S2e/S3). The term "expert consensus (EC)" to be used is synonymous with terms from other guidelines such as "good clinical practice (GCP)" or "clinical consensus point (CCP)". The recommendation strength is graded similarly to the aforementioned classification without the use of the symbols and is expressed in purely semantic terms ("must"|“must not" or "should"|"should not" or "may"|"does not need to").

\section{Guideline}

\section{$1 \quad$ Epidemiology and Risk Factors}

1.1 VIN: incidence, tumor staging

Consensus-based statement 1. S1

The incidence of VIN is on the rise. The mean age at diagnosis has decreased significantly (expert consensus).

\section{Strength of consensus (+++)}

VIN are divided into:

- undifferentiated (usual type, classic) VIN = uVIN

- differentiated (differentiated type) VIN = dVIN

The prognosis of untreated VIN varies widely. VIN can persist, disappear again or develop into invasive cancer. One study reported that approximately $10 \%$ of cases with VIN ( 8 out of 88 patients), experienced progression to invasive carcinoma within 18 years [1]. Half of these cases had additional risk factors such as pelvic radiation therapy of the lower genital tract or immunosuppression. Spontaneous remission occurred particularly among patients younger than 35 years of age [2].

\subsection{Paget's disease of the vulva}

Extramammary Paget's disease is rare and accounts for only around $1 \%$ of vulvar malignancies. The disease is most common in the 7th decade of life; the mean age at diagnosis is 69 years. Concurrent malignancies are identified in $30 \%$ of cases, with breast cancer and urothelial cancer reported to be the most common concurrent tumor types [3-5]. 


\subsection{Invasive carcinoma}

\section{Consensus-based statement 1. S2}

The incidence of invasive vulvar cancer has increased significantly and stands currently at 5.8/100000 women/year. The mean age at diagnosis has decreased significantly (expert consensus).

\section{Strength of consensus (+++)}

Vulvar cancer is the fourth most common cancer of the female genital tract. The number of new cases with vulvar cancer has doubled in the last 10 years [6], meaning that the overall incidence of vulvar cancer is increasing. According to data of the RKI, the incidence of vulvar cancer in Germany in 2010 was 4.6/ 100000 women/year with around 3200 new cases annually. The estimated figures for 2014 are an incidence of 5.8/100000 women/year with 4000 new cases of vulvar cancer in that year (www. rki.de/Krebs/DE/Content/Publikationen/Krebs-in-Deutschland/ kid-2013-c51-vulva.pdf). In 2010, the relative 5-year survival rate in Germany for all stages of disease was $71 \%$.

\subsection{Risk factors}

Keratinizing vulvar cancers are not associated with HPV infection. Degenerative and chronic inflammatory skin diseases are important risk factors for this type of cancer, particularly lichen sclerosus which is associated with a $4-5 \%$ lifelong risk of cancer [7]. Non-keratinizing squamous cell carcinoma of the vulva tends to be associated with HPV infection and usually occurs in younger women (mean age at diagnosis is 55 years). Other risk factors include smoking [8-11] and immunosuppression, e.g. after organ transplantation or due to HIV infection.

\section{Prevention and Early Detection \\ 2.1 Primary prevention}

Consensus-based statement 2. S3

Primary prevention of the subgroup of HPV-associated invasive vulvar cancers and their precursor lesions is possible by avoiding genital infection with HPV (expert consensus).

Strength of consensus (+++)

Consensus-based recommendation 2. E1

HPV vaccination should* also be recommended in the context of preventing VIN lesions and vulvar cancer [12] (expert consensus).

\section{Strength of consensus (+++ 2 biased)}

* Note: used analogously to "should" as defined for the S3 guideline on HPV vaccination

Vaccination with one of the prophylactic HPV vaccines is considered a means of primary prevention, as around $85 \%$ of all highgrade VIN lesions (HSIL) and approximately $40 \%$ of all vulvar cancers are positive for HPV [13-15]. The two most common forms of HPV associated with VIN are types 16 and 18 while the types most commonly associated with vulvar cancer are types 16 and 33. Based on the currently available data, HPV vaccination should be recommended as it additionally serves to prevent VIN lesions and vulvar cancer (see also "S3 Guideline on the Prevention of HPV-associated Neoplasia through Vaccination", AWMF registry number 082/002). According to the recommendation of the German Standing Vaccination Committee (STIKO) at the Robert Koch Institute published in August 2014 [16], HPV vaccination is recommended for all young girls aged between 9 and 14 years. All girls who have not received the vaccination by this age should be vaccinated before they reach the age of 17 years.

\subsection{Secondary prevention}

Consensus-based recommendation 2. E2

There is no specific screening to detect vulvar cancer and its precursor lesions. Examination of all of the vulva must be an essential part of gynecological cancer screening (expert consensus).

Strength of consensus (+++)

\section{Structure of Care}

Consensus-based recommendation 3. E3

Patients with vulvar cancer should be managed by an interdisciplinary and interprofessional team. This team should consist of a cross-sectoral network of persons from all relevant medical specialties and professions. This is most easily achievable in a certified center (expert consensus).

Strength of consensus $(++)$

Minority vote: The following 3 organizations do not support the last sentence: VulvaKarzinom-Selbsthilfegruppe e.V. [Vulvar Cancer Self-help Group]; Berufsverband der Frauenärzte e.V. (BVF) [Professional Association of German Gynecologists]; Deutsche Röntgengesellschaft e.V. (DRG) [German Radiological Society].

Consensus-based recommendation 3. E4

All cases of vulvar cancer must be presented to and discussed by an interdisciplinary tumor board (expert consensus).

Strength of consensus (++)

$4 \quad$ Pathology

4.1 Classification of precancerous lesions

(๑ Table 3)

Consensus-based recommendation 4. E5

The terminology and morphological diagnosis of precancerous vulvar lesions (vulvar intraepithelial neoplasia, VIN) must be based on the nomenclature used in the most current version of the WHO classification (expert consensus).

Strength of consensus $(+++)$

\subsection{Paget's disease of the vulva}

Consensus-based recommendation 4. E6

To exclude or detect (micro-)invasion, biopsied specimens should be examined in step sections to obtain a histological verification of Paget's disease of the vulva (expert consensus).

Strength of consensus $(+++)$

\subsection{Morphology of invasive vulvar cancer}

Consensus-based statement 4. S4

Micrometastasis is defined as histological evidence of tumor cells in lymph nodes with a diameter of $\geq 0.2 \mathrm{~mm}$ but not more than $2 \mathrm{~mm}$ (expert consensus).

Strength of consensus $(+++)$ 
Table 3 Nomenclature for HPV-associated and non-HPV-associated precancerous vulvar lesions [17-24].

\begin{tabular}{|c|c|c|c|c|c|}
\hline \multirow[t]{2}{*}{ Source } & \multicolumn{5}{|l|}{ Description } \\
\hline & $\begin{array}{l}\text { Condylomatous } \\
\text { lesion }\end{array}$ & Mild dysplasia & $\begin{array}{l}\text { Moderate } \\
\text { dysplasia }\end{array}$ & $\begin{array}{l}\text { Severe dysplasia, } \\
\text { carcinoma in situ }\end{array}$ & $\begin{array}{l}\text { HPV-negative lesions with atypical } \\
\text { keratinocytes in the basal cell layer }\end{array}$ \\
\hline WHO 2003 & VIN 1 & & VIN 2 & VIN 3 & VIN 3 \\
\hline ISSVD*2005 & \multicolumn{2}{|c|}{ HPV-associated changes } & \multicolumn{2}{|c|}{ classic VIN, usual type, u-VIN } & differentiated VIN, d-VIN \\
\hline WHO 2014 & \multicolumn{2}{|c|}{$\begin{array}{l}\text { low-grade squamous intraepithelial lesion } \\
\text { LSIL** }\end{array}$} & \multicolumn{2}{|c|}{$\begin{array}{l}\text { high-grade squamous intraepithelial lesion } \\
\text { HSIL** }\end{array}$} & $\begin{array}{l}\text { differentiated type vulvar } \\
\text { intraepithelial neoplasia (d-VIN) }\end{array}$ \\
\hline ISSVD* 2015\# & \multicolumn{2}{|c|}{$\begin{array}{l}\text { low grade squamous intraepithelial lesion } \\
\text { (flat condyloma or HPV effect) }\end{array}$} & \multicolumn{2}{|c|}{$\begin{array}{l}\text { high grade squamous intraepithelial lesion } \\
\text { (VIN usual type) }\end{array}$} & $\begin{array}{l}\text { intraepithelial neoplasia, } \\
\text { differentiated type }\end{array}$ \\
\hline
\end{tabular}

* ISSVD = International Society for the Study of Vulvo-vaginal Disease [22, 23]

** The term VIN is used synonymously in the WHO classification.

\# Information issued by the ISSVD and sent to members in 2015 by J. Bernstein (Chairman of the 2013-2015 ISSVD Terminology Committee)

http://issvd.org/wp-content/uploads/2015/09/2015-ISSVD-VIN-terminology-for-the-website-v5.pdf

\subsection{Preparation of tissue samples \\ 4.5.1 Diagnostic biopsies}

Consensus-based recommendation 4. E7

Biopsied material which was sampled because of a suspicion of VIN must be examined in step sections (expert consensus).

Strength of consensus (+++)

Consensus-based recommendation 4. E8

The information in the findings report must include evidence for VIN, the type of VIN, the presence or absence of any dermatologic disorder, the presence or absence of virus-associated changes, and the presence or absence of invasion (expert consensus).

Strength of consensus (+++)

\subsubsection{Tissue samples after local (radical) excision,} (radical) vulvectomy and lymphadenectomy

Consensus-based recommendation 4. E9

Morphological examination of tissue specimens must be carried out such that all therapeutically and prognostically relevant parameters can be determined. The diagnosis must be based on the most recent relevant WHO classification of tumor types and use the most recent TNM classification for staging (expert consensus).

Strength of consensus (+++)

Consensus-based recommendation 4. E10

The pathologist's report on the findings in the vulvar samples and on vulvar cancer must include the following information:

- histological type according to the WHO classification

- tumor grade

- evidence/absence of lymphatic vessel or blood vessel invasion (L-status and V-status)

- evidence/absence of perineural sheath infiltration (Pn-status)

- staging (pTNM)

- maximum depth of invasion and extent of tumor (in $\mathrm{mm}$ ) for stages pT1a and pT1b

- 3-dimensional tumor size in cm (from pT1b)

- metric data on the minimal distance from the cancer or VIN to the vulvar resection margin

- after resection of the vulvo-vaginal, vulvo-anal area and/or urethra, metric data on the minimal width of the vulvo-vaginal, vulvo-anal or urethral resection margin metric data on the minimal width of the soft tissue resection margin (basal margin)

- R-classification (UICC), where relevant (expert consensus)

Strength of consensus (+++)

Consensus-based recommendation 4. E11

When surgery is indicated for vulvar cancer, every lymph node resected during lymphadenectomy must be submitted for histological examination (expert consensus).

Strength of consensus (+++)

\section{Consensus-based recommendation 4. E12}

Lymph nodes with diameters of up to $0.3 \mathrm{~cm}$ should be completely embedded; larger lymph nodes should be halved along their longitudinal plane and also completely embedded for examination (expert consensus).

Strength of consensus $(+++)$

Consensus-based recommendation 4. E13

The findings report on lymph node preparations must include the following information:

- the number of lymph nodes with tumor involvement compared to the overall number of resected lymph nodes together with information about the site of resection (which side, bilateral/unilateral, inguinal/pelvic)

- the absence/presence of extracapsular growth of the lymph node metastasis

- the presence of isolated tumor cells in the lymph node along with any evidence of lymphatic vessel infiltration into perinodal adipose tissue and/or the lymph node capsule

- maximum diameter of the metastasis (expert consensus)

Strength of consensus (+++)

For more details on information which should be included in the histological reporting of lymph nodes specimens, cf. [25-27].

\subsubsection{Sentinel lymph nodes}

\section{Consensus-based recommendation 4. E14}

Sentinel lymph nodes resected from patients with vulvar cancer must be completely embedded and examined in step sections. In addition, lymph nodes which are morphologically unremarkable on $\mathrm{H} \& \mathrm{E}$ must be examined by immunohistochemistry (so-called ultrastaging) (expert consensus).

Strength of consensus (+++) 
Table 4 Prognostic factors for vulvar cancer $\geq$ stage pT1b.

\begin{tabular}{|c|c|c|c|}
\hline Name & Standard factor & Risk/prognostic factor & Relevant for therapy \\
\hline Tumor stage & yes & yes & yes \\
\hline Lymph node status & yes & yes & yes \\
\hline Size of inguinal LN metastasis & yes & yes & yes \\
\hline Number of inguinal LN positive for metastatic disease & yes & yes & yes \\
\hline Extracapsular growth of inguinal LN metastasis & yes & yes & yes \\
\hline Perineural sheath infiltration (Pn-status) & yes & unclear & no \\
\hline Lymphatic vessel infiltration (L-status) & yes & unclear & no \\
\hline Invasion of the vein (V-status) & yes & unclear & no \\
\hline Resection margins (residual tumor status; R-status) & yes & yes & yes \\
\hline Depth of invasion in $\mathrm{mm}$ & yes & yes & no \\
\hline Grade & yes & unclear & no \\
\hline 3-dimensional tumor size in $\mathrm{cm}$ & yes & unclear & no \\
\hline Ulceration of the cancer & no & no & no \\
\hline Multifocal carcinoma & yes & unclear & yes (surgery) \\
\hline Peritumoral VIN & yes & unclear & yes (surgery) \\
\hline Histological tumor type & yes & yes & yes (LND yes/no) \\
\hline Evidence of HPV in the cancer & no & unclear & no \\
\hline Pattern of invasion & no & unclear & no \\
\hline Extent of metastasis in the affected LN & no & unclear & no \\
\hline Bilateral inguinal LN metastasis & yes & no & yes \\
\hline Immunohistochemical ultrastaging of $\mathrm{LN}$ for metastasis & no & unclear & unclear \\
\hline Molecular marker & no & no & no \\
\hline
\end{tabular}

\subsection{Morphologic prognostic factors}

Established prognostic factors for vulvar cancer include the tumor stage, the presence of inguinal or pelvic lymph node metastasis [28-37]; the size of regional lymph node metastases, the presence of extracapsular growth and the number of lymph nodes with metastatic disease $[30,31,35,36,38-44]$. The individual criteria for tumors $\geq$ stage pT1b are listed in $\bullet$ Table 4.

\section{Diagnosis \\ 5.1 Medical history}

Consensus-based recommendation 5. E15

Early symptoms of vulvar cancer and its precursor lesions are often unspecific or absent. Therapy-resistant symptoms which persist for several weeks must be investigated in a detailed clinical work-up (expert consensus).

Strength of consensus (+++)

\subsection{Clinical examination}

\section{Consensus-based recommendation 5. E16}

If symptoms are suspicious for vulvar cancer, the diagnosis must be primarily based on the clinical work-up. The basis of the clinical work-up is careful inspection of the area with additional vulvoscopy and palpation of the area including the inguinal region. Biopsies must be taken if findings are suspicious (expert consensus).

\section{Strength of consensus (+++)}

The following methods are used to identify precancerous lesions and carcinomas:

- clinical examination, consisting of inspection and palpation

- vulvoscopy with the application of acetic acid

\subsection{Histological work-up}

Consensus-based recommendation 5. E17

All suspicious lesions must be examined histologically (expert consensus).

Strength of consensus (+++)

\subsection{Cancer staging prior to starting treatment}

Consensus-based recommendation 5. E18

If there is evidence of invasion, the following examinations must be done prior to starting treatment:

- determination of the depth of infiltration

- gynecological examination of the entire anogenital area

v determination of the clinical tumor size (vulvoscopy in preparation for surgery)

- determination of tumor location and extent of tumor spread as well as documentation of any extension of the tumor to the urethra, vagina, anus, bones

- determination of multicentric status

- examination of regional lymphatic pathways (palpation of the inguinal region, imaging depending on tumor stage)

(expert consensus)

Strength of consensus $(+++)$

Imaging work-up should only be done for tumors with a diameter $>2 \mathrm{~cm}$ or where there is infiltration of the urethra, vagina or anus. MRI is the imaging method of choice to assess local tumor extension because of its superior soft tissue contrast; contrastenhanced CT is used to search for distant metastasis [45, 46]. Published data on the appropriate imaging method to detect inguinal lymph node metastasis in patients with primary vulvar cancer are summarized in $\bullet$ Table 5 . 


\subsubsection{Examination of regional lymphatics ( $\bullet$ Table 5)}

Table 5 Imaging method of choice to detect inguinal lymph node metastasis [47-55].

\begin{tabular}{|c|c|c|c|c|c|c|c|c|c|c|}
\hline Imaging method & MRI & MRI & MRI & MRI & MRI & СT & $\begin{array}{l}\text { FDG- } \\
\text { PET }\end{array}$ & US & US & US \\
\hline $\begin{array}{l}\text { LN size } \\
\text { Location }\end{array}$ & $\begin{array}{l}\geq 10 \mathrm{~mm} \\
\mathrm{TD}^{*}\end{array}$ & $\begin{array}{l}\geq 10 \mathrm{~mm} \\
\text { TD }\end{array}$ & $\begin{array}{l}\geq 8 \mathrm{~mm} \\
T D\end{array}$ & $\begin{array}{l}\geq 5 \mathrm{~mm} \\
\text { TD }\end{array}$ & $\begin{array}{l}>8 \mathrm{~mm} \\
\text { TD } \\
\text { deep/ } \\
\text { femoral }\end{array}$ & $\begin{array}{l}>10 \mathrm{~mm} \\
\mathrm{LD}^{\#}\end{array}$ & & $>8 \mathrm{~mm}$ & $\begin{array}{l}\text { long axis/ } \\
\text { short axis } \\
\text { ratio }<2\end{array}$ & $\geq 4 \mathrm{~mm}$ \\
\hline Sensitivity & $89 \%$ & $86 \%$ & $52 \%$ & $87 \%$ & $50 \%$ & $58 \%$ & $67 \%$ & $83 \%$ & $87 \%$ & $76 \%$ \\
\hline Specificity & $91 \%$ & $82 \%$ & $89 \%$ & $81 \%$ & $100 \%$ & $75 \%$ & $95 \%$ & $90 \%$ & $69 \%$ & $91 \%$ \\
\hline Negative predictive value & $91 \%$ & $64 \%$ & $89 \%$ & & & $58 \%$ & $86 \%$ & $97 \%$ & $48 \%$ & $88 \%$ \\
\hline Positive predictive value & $89 \%$ & $94 \%$ & $52 \%$ & & & $75 \%$ & $86 \%$ & $62 \%$ & $94 \%$ & $83 \%$ \\
\hline References & Hawnaur & Singh & Bipat & Kataoka & Sohaib & Land & Cohn & $\begin{array}{l}\text { Abang Mo- } \\
\text { hammed }\end{array}$ & Land & $\begin{array}{l}\text { de } \\
\text { Gregorio }\end{array}$ \\
\hline
\end{tabular}

* $\mathrm{TD}=$ max. transverse diameter, ${ }^{\#} \mathrm{LD}=$ max. longitudinal diameter

\subsection{Diagnostic work-up for advanced tumors}

Consensus-based recommendation 5. E19

Imaging and endoscopy should only be used for specific indications (expert consensus).

Strength of consensus (+++)

Consensus-based recommendation 5. E20

The search for distant metastasis should only be done in patients with advanced vulvar cancer (FIGO > II) (expert consensus).

Strength of consensus (+++)

\subsection{Staging}

Staging is done in accordance with the FIGO and TNM classification systems. The final diagnosis is based on the findings at surgery and the results of the histopathological examination of surgical specimens ( Table 6 ).

\section{$7 \quad$ Treatment of VIN and Paget's Disease}

Consensus-based statement 7. S5

There is no reliable data on the adequate margin of healthy tissue when resecting HSIL, including multifocal HSIL (expert consensus).

Strength of consensus (+++)

Consensus-based recommendation 7. E31

HSIL and dVIN lesions must either be resected by histologically complete excision or removed by laser evaporation until tissue margins are healthy. Excision should be used to treat dVIN lesions while laser evaporation is the treatment of choice for HPV-associated HSIL (expert consensus).

\section{Strength of consensus (+++)}

The use of topical 5\% imiquimod represents an 'off-label' use. According to recent data, response rates of up to $50 \%$ have been reported for HSIL; however, long-term follow-up data are lacking [58-63].
Table 6 FIGO/TNM classification of vulvar cancer $[56,57]$.

\begin{tabular}{|c|c|c|}
\hline UICC & FIGO & Tumor spread \\
\hline & Tis & Carcinoma in situ, vulvar intraepithelial neoplasia (VIN) 3 \\
\hline T1 & I & Tumor confined to the vulva or vulva and perineum \\
\hline T1a & IA & $\begin{array}{l}\text { Maximum size of lesion: } 2 \mathrm{~cm} \text { or less, stromal invasion } \\
\text { less than } 0.1 \mathrm{~cm}\end{array}$ \\
\hline $\mathrm{T} 1 \mathrm{~b}$ & IB & $\begin{array}{l}\text { Maximum size of lesion: }>2 \mathrm{~cm} \text {, stromal invasion } \\
>0.1 \mathrm{~cm}\end{array}$ \\
\hline $\mathrm{T} 2$ & II & $\begin{array}{l}\text { Tumor has infiltrated one of the following adjacent } \\
\text { structures: lower third of the urethra, vagina or anus }\end{array}$ \\
\hline T3 & IVA & $\begin{array}{l}\text { Tumor has infiltrated one of the following adjacent } \\
\text { structures: upper two thirds of the urethra, vagina, } \\
\text { bladder mucosa, rectal mucosa or fixed to bone }\end{array}$ \\
\hline NO & & No regional lymph node metastasis \\
\hline N1 & & $\begin{array}{l}\text { Regional lymph node metastasis with the following } \\
\text { characteristics: }\end{array}$ \\
\hline N1a & IIIA(ii) & 1 or 2 lymph node metastases, each smaller than $0.5 \mathrm{~cm}$ \\
\hline N1b & IIIA(i) & 1 lymph node metastasis, $0.5 \mathrm{~cm}$ or larger \\
\hline N2 & & $\begin{array}{l}\text { Regional lymph node metastasis with the following } \\
\text { characteristics: }\end{array}$ \\
\hline $\mathrm{N} 2 \mathrm{a}$ & IIIB(ii) & $\begin{array}{l}3 \text { or more lymph node metastases, each smaller } \\
\text { than } 5 \mathrm{~mm}\end{array}$ \\
\hline $\mathrm{N} 2 \mathrm{~b}$ & IIIB(i) & 2 or more lymph node metastases, $5 \mathrm{~mm}$ or larger \\
\hline $\mathrm{N} 2 \mathrm{C}$ & IIIC & Lymph node metastasis with extracapsular spread \\
\hline N3 & IVA(ii) & Fixed or ulcerated regional lymph node metastasis \\
\hline M0 & & No distant metastasis \\
\hline M1 & IVB & $\begin{array}{l}\text { Any distant metastasis (including pelvic lymph node } \\
\text { metastasis) }\end{array}$ \\
\hline
\end{tabular}

Consensus-based recommendation 7. E32

The primary treatment for extramammary Paget's disease consists of surgical excision of the lesion. Surgical excision should include wide excision margins extending well into healthy tissue, both in the horizontal and the vertical planes.

Depending on the location and size of the lesion, plasty may be considered to cover the defect, with careful attention paid to any comorbidities (expert consensus).

Strength of consensus $(+++)$ 
8

8.1 Standard treatment for primary vulvar cancer

The appropriate treatment should be decided on by an interdisciplinary (gynecologic oncology, radiation therapy, pathology, anesthesiology) board.

\subsection{Surgery of the vulva}

\section{Consensus-based recommendation 8. E33}

The surgical specimen must be excised in such way that an R0 resection status is achieved on all sides. The minimum tumor-free tissue margin should be at least $3 \mathrm{~mm}$ on histological examination (expert consensus).

\section{Strength of consensus (+++)}

While the ultimate goal is excision with a margin of healthy tissue, whether by local excision or vulvectomy, the following general principle applies: the greater the distance between the tumor and the edge of the resection margin, the lower the probability of local recurrence. It is not possible to define an evidencebased cut-off for the minimum width of tumor-free resection margins. The expert consensus can be summarized as follows: the margin of healthy tissue must be at least $3 \mathrm{~mm}$ (measured histologically); clinical dissection should therefore extend even further. In individual cases, after informing the patient about the potentially higher risk of recurrence, accepting quite narrow ablation margins may be the right thing to do, for example to avoid resection of the clitoris or of the external urethral orifice. The goal of resection into healthy tissue does not just apply to tumors with invasive growth but also includes potential intraepithelial neoplastic neoplasia (VIN) directly adjacent to the tumor.

\section{Consensus-based recommendation 8. E34}

If vulvectomy is indicated and there is no increased risk of skin bridge metastasis, the approach must be the triple incision technique, i.e. vulvectomy and lymphadenectomy are performed using different incisions (expert consensus).

\section{Strength of consensus (+++)}

Local radical excision must, wherever possible, be the surgical method of choice. Complete vulvectomy should only be performed if it is unavoidable due to tumor spread. If it is necessary to perform complete vulvectomy, the recommended approach is the triple incision technique, i.e. vulvectomy and inguinal lymphadenectomy are performed using different incisions.

\section{Consensus-based recommendation 8. E35}

After local excision or vulvectomy, primary reconstruction plasty (pudendal flaps, Limberg flaps or others) should be considered; careful attention is necessary to ensure tension-free coverage of the wound, good functionality and appearance (expert consensus).

\section{Strength of consensus (+++)}

Reconstructive plasty to cover the wound [64] after resection with a focus on functionality and body image should not just be performed in younger patients but should be done in all patients, irrespective of age, as this makes it more likely that coverage of the defect will be tension-free and will prevent wound dehiscence with longer secondary healing in all age groups.

When deciding whether reconstructive surgery is indicated it is important to take account of any patient comorbidities such as age, diabetes mellitus, hypertension, or nicotine abuse.

\subsection{Recommendations for treatment according to stage \\ 8.3.1 Stage $\mathrm{T} 1$}

Consensus-based recommendation 8. E36

Unifocal stage T1a or T1b vulvar cancer must be treated by local resection into healthy tissue (radical local excision) (expert consensus).

Strength of consensus (+++)

\subsubsection{Stage $\mathrm{T} 2$}

Consensus-based statement 8. 56

Depending on the clinical status, local radical excision or vulvectomy combined with resection of any involved structures of the urethra, vagina, or anus is indicated for stage T2 disease.

Primary radio(chemo)therapy is an alternative if surgery would otherwise put continence at risk (expert consensus).

\section{Strength of consensus (+++)}

\subsubsection{Stage T3 (equivalent to FIGO stage IVA)}

Consensus-based recommendation 8. E37

Primary radiochemotherapy should be done if stage T3 (= FIGO stage IVA) lesions are present to preserve the function of adjacent organs (micturition and/or defecation) where possible. Alternatively, patients should receive neoadjuvant radio(chemo)therapy to reduce the extent of subsequent surgery (expert consensus).

Strength of consensus (+++)

Consensus-based recommendation 8. E38

If there is infiltration into adjacent organs and/or fistula formation, primary exenteration should be performed if there is no distant metastasis.

Primary exenteration should also be done as a palliative therapy when infiltration into adjacent organs and/or fistula formation has occurred (expert consensus).

Strength of consensus (+++)

\section{$9 \quad$ Lymphatic Vessel Surgery}

\subsection{Lymphatic drainage of the vulva}

The lymphatics of the vulva drain exclusively to the inguinal and femoral lymph nodes. There is no risk of skip metastasis to the pelvic lymph nodes.

\subsection{Extent of lymphadenectomy}

Consensus-based recommendation 9. E39

Systematic inguinofemoral lymphadenectomy (= surgical staging of the inguinal region) must always include removal of both the superficial (inguinal) and the deep (femoral) lymph nodes below the cribriform fascia (expert consensus).

Strength of consensus (+++)

The rule of thumb is that at least 6 lymph nodes should be resected from either side [57]. 
Consensus-based recommendation 9. E40

Staging of the inguinofemoral lymph nodes must not be done in cases with stage pT1a vulvar cancer (infiltration depth $1 \mathrm{~mm}$ or less), basal cell carcinoma, or verrucous carcinoma of the vulva (expert consensus).

Strength of consensus (+++)

Consensus-based recommendation 9. E41

Surgical staging of the inguinofemoral lymph nodes must be done in cancers where the infiltration depth is more than $1.0 \mathrm{~mm}$ ( $\geq$ pT1b) (expert consensus).

Strength of consensus (+++)

\subsection{Lateral tumor and contralateral LN}

Consensus-based recommendation 9. E42

Contralateral lymph node staging may be dispensed with in lateral cancers ( $>1 \mathrm{~cm}$ distance to the midline) with diameters of less than $2 \mathrm{~cm}$ if the ipsilateral lymph nodes are histologically tumorfree. Surgical staging of the contralateral side must be performed in all other cases (expert consensus).

Strength of consensus (+++)

\subsection{Complications of inguinofemoral} lymphadenectomy

Inguinofemoral lymphadenectomy is associated with significant morbidity [65-70]:

- impaired wound healing in $14-44 \%$ of cases

- lymphoceles in $13-40 \%$ of cases

- lymphedema (requiring treatment) of the leg in $20-35 \%$ of cases

\subsection{Sentinel lymphadenectomy}

Consensus-based recommendation 9. E43

Patients with unifocal primary tumor with a diameter $<4 \mathrm{~cm}$ and clinically negative inguinofemoral lymph nodes must be informed about the benefits and possible oncologic risks of sentinel lymphadenectomy and of systematic inguinofemoral lymphadenectomy. If no sentinel lymphadenectomy is performed, patients must undergo inguinofemoral lymphadenectomy (expert consensus).

Strength of consensus (+++)

Consensus-based recommendation 9. E44

The following conditions must be met for sentinel lymph node biopsy to be indicated:

- maximum tumor diameter at skin level $<4 \mathrm{~cm}$

$\checkmark$ unifocal tumor

- inguinofemoral lymph nodes must be clinically and sonographically unremarkable

- team must be experienced in marking sentinel lymph nodes

- ultrastaging of the lymph nodes must be done with additional immunohistochemical examination by a pathologist

- the patient must be informed in detail about the benefits and possible oncologic risks of the method

- the patient must be followed up regularly (good patient compliance) (expert consensus)

Strength of consensus (+++)

\subsection{Pelvic lymph nodes}

Pelvic lymphadenectomy can be considered as part of a multimodal treatment plan with additional radiation therapy in patients who undergo tumor debulking if there is evidence of enlarged pelvic LN. Pelvic lymphadenectomy may be considered in patients with inguinal lymph node metastasis and an increased risk of pelvic LN involvement when the aim is to avoid adjuvant pelvic radiation therapy if pelvic $\mathrm{LN}$ are negative.

\section{Radiotherapy and Radiochemotherapy \\ 10.1 Postoperative (adjuvant) radiotherapy \\ 10.1.1 Postoperative tumor bed irradiation}

Consensus-based recommendation 10. E45

Postoperative irradiation of the tumor bed must be done after R1/ $\mathrm{R} 2$ resection.

Tumor bed irradiation should be considered if the resection margin in health tissue is $3 \mathrm{~mm}$ (in the histological specimen) or less and a second resection is not possible or/and functionally not expedient or the patient does not want it (expert consensus).

Strength of consensus (+++)

\subsubsection{Postoperative irradiation of the inguinal lymphatics}

Consensus-based recommendation 10. E46

Postoperative irradiation of the affected inguinal region(s) should be done:

- if lymph node involvement is present with involvement of 2 or more inguinal lymph nodes, irrespective of the size of the metastases

- if one lymph node is affected and the metastasis is at least $5 \mathrm{~mm}$ or larger

- always if extracapsular growth is present (FIGO IIIC)

- if fixed/ulcerated lymph nodes are present (FIGO IVAii) (expert consensus)

Strength of consensus (+++)

\subsubsection{Postoperative irradiation of pelvic lymphatics}

Consensus-based recommendation 10. E47

To avoid overtreatment and unnecessary therapy-related toxicity, postoperative irradiation of the pelvic lymphatics should be reserved for patients with histologically verified pelvic lymph node metastasis (expert consensus).

Strength of consensus (+++)

Laparoscopic or extraperitoneal pelvic lymphadenectomy is recommended to obtain the histological lymph node status if

- lymph node involvement is present with involvement of 2 or more inguinal lymph nodes, irrespective of the size of the metastases

- one inguinal lymph node is affected and the metastasis is at least $5 \mathrm{~mm}$ or greater

- extracapsular growth in an inguinal lymph node is present (FIGO IIIC)

- fixed/ulcerated inguinal lymph nodes are present (FIGO IVAii) Irradiation of the pelvic lymphatics should only be done if lymph nodes are positive [71]. 
Table 7 Follow-up for vulvar cancer; examinations and intervals.

\begin{tabular}{|lllll}
\hline Interval (years) & Frequency (months) & Mandatory examinations & Symptom-related examination & Comments \\
$1-3$ & every 3 months & history, clinical examination & imaging & biopsy of suspicious region \\
\hline $4-5$ & every 6 months & history, clinical examination & imaging & biopsy of suspicious region \\
\hline$\geq 6$ & every 12 months & history, clinical examination & imaging & biopsy of suspicious region \\
\hline
\end{tabular}

\subsection{Primary radiotherapy}

10.2.1 Primary radiochemotherapy

Primary radiochemotherapy can be administered to treat invasive cancer if the patient requests it (to preserve the organ) or if the cancer is inoperable.

\subsubsection{Neoadjuvant radiochemotherapy}

In patients with locally advanced vulvar cancer, chemoradiation may achieve a reduction in tumor size in $63-92 \%$ of cases, making the cancer operable [72].

\subsubsection{Simultaneous chemotherapy}

As with other squamous cell carcinomas, combined radiochemotherapy can also be used to treat locally advanced vulvar cancer. The most common combination is 5-fluorouracil with cisplatin or mitomycin C.

\section{Systemic Therapy}

The experience with systemic therapy to treat vulvar cancer is very limited.

\subsection{Neoadjuvant chemotherapy}

Neoadjuvant chemotherapy is not yet an established treatment option to treat vulvar cancer. Platinum-based combination chemotherapy has a reported clinical response rate of up to $80 \%$ and complete pathological remission rates of up to $45 \%$ [73]. In contrast to primary radiochemotherapy (cf. relevant chapter on the indications for and administration of primary radiochemotherapy) the goal of neoadjuvant chemotherapy is subsequent surgical resection. When making the decision for treatment, this approach can be considered for selected patients in a suitable general state of health.

\section{6}

$$
\text { Follow-up }
$$

Consensus-based recommendation 16. E61

Follow-up must consist of:

- disease-specific history

- symptom-related history: palpated tumor, pain, pruritus, vaginal discharge, bleeding, leg edema, propensity for swelling, symptoms of scarring and stenosis, micturition anomalies

- clinical examination:

> inspection and palpation of the external and internal genitalia including the inguinal lymphatics and the rectum

- speculum examination

- broad indication for biopsy of suspicious findings

(expert consensus)

Strength of consensus (+++)
Consensus-based recommendation 16. E62

If lichen sclerosus of the vulva is present, this will significantly affect the probability of recurrence or new-onset of vulvar cancer. Lifelong follow-up must therefore be done in patients with this condition (expert consensus).

Strength of consensus $(+++)$

Consensus-based recommendation 16. E63

The routine use of imaging methods is not indicated in follow-up but can be helpful when the status is unclear or suspicious for recurrence. Determination of the tumor marker SCC must not be part of follow-up (expert consensus).

Strength of consensus $(+++)$

Consensus-based statement 16. S8

Colposcopy of the cervix, vagina, vulva and anus is an additional useful examination (expert consensus).

Strength of consensus $(+++)$

Consensus-based recommendation 16. E64

Lifelong follow-up should be done in patients with treated HSIL or d-VIN (expert consensus).

Strength of consensus (+++)

\subsection{Follow-up intervals ( $\bullet$ Table 7)}

17 Locoregional Recurrence and Distant Metastasis The majority of all recurrences occur within the first 2 years after primary therapy $[6,28,74-84]$. Around $65 \%$ of these recurrences are detected clinically during routine follow-up [74].

\subsection{Diagnostic work-up for suspicion of recurrence}

If there is a suspicion of vulvar cancer recurrence the first step should consist of histological verification. Once the recurrence has been verified histologically, a diagnostic work-up to determine the extent of spread of disease should be done, particularly if there is inguinal recurrence. This diagnostic work-up can consist of MRI of the pelvis, CT of the thorax/abdomen and possibly scalene node biopsy [85]. FDG-PET-CT at primary diagnosis has a high predictive value in the search for distant metastasis.

\subsection{Treatment of local recurrence without involvement of the urethra or anus}

Consensus-based recommendation 17. E65

Treatment of local recurrence should consist of resection with cancer-free resection margins (R0) (expert consensus).

Strength of consensus (+++) 


\subsection{Treatment of local recurrence when $\mathrm{R} 0$ resection is not possible}

Consensus-based recommendation 17. E66

The treatment of choice for inoperable recurrence should be chemoradiotherapy or radiation therapy (expert consensus).

Strength of consensus (+++)

Consensus-based recommendation 17. E67

If locoregional recurrence occurs in a previously irradiated region and surgery or repeated radiotherapy is not an option, the patient should receive palliative care (expert consensus).

\section{Strength of consensus (+++)}

\subsection{Treatment of recurrence with involvement of the urethra, vagina and anus}

Staging of the lesion should be done prior to starting any treatment. If recurrence involves adjacent organs such as the urethra and/or anus, then primary radio(chemo)therapy is usually indicated if the patient has not previously had radiotherapy. If distant metastasis has been excluded, one treatment option is pelvic exenteration. The few existing studies have reported a 5-year survival rate of $31-38 \%$, with longer survival times documented for individual cases [86-91].

\subsection{Treatment of inguinal recurrence}

Consensus-based recommendation 17. E68

Distant metastasis must be excluded prior to carrying out radical surgery for inguinal and/or pelvic recurrence (expert consensus). Strength of consensus (+++)

Inguinal or pelvic recurrence is usually a sign that treatment can only be palliative rather than curative; the prognosis is poor, with a 5 -year survival rate of $5-27 \%$. In patients who have not had prior radiation therapy, local excision followed by radiotherapy or radiochemotherapy should be performed. If the affected inguinal region was previously treated with adjuvant radiotherapy, the only remaining option is that of best supportive care $[92,93]$.

\subsection{Treatment for distant metastasis}

Consensus-based recommendation 18. E69

Because of the poor response rates, monotherapy should be the systemic therapy of choice. The diagnostic criteria for prescribing systemic therapy should be very strict (expert consensus).

Strength of consensus (+++)

\subsection{Note on radiochemotherapy}

When considering whether radiation therapy is indicated to treat recurrence of vulvar cancer, there is always the question whether it should take the form of straightforward radiotherapy or be administered in the form of radiochemotherapy. Unfortunately, there are no comparative randomized studies available which would clarify this issue.

\section{Note}

Chapters on more general topics which did not exclusively apply to vulvar cancer such as the chapters on Patient Information (6), Supportive Therapy (12), Psychooncology and Quality of Life (13), Rehabilitation (14), Integrative Medicine (15) and Palliative Medical Care (18) can be consulted in the long version of the guideline.

During the compilation of this guideline, quality indicators were developed as part of the methodological framework; they are included in a separate chapter in the long version of this guideline (19).

\section{Affiliations}

1 ehem. Frauenklinik Lukaskrankenhaus, Neuss

2 Frauenklinik, Klinikum Darmstadt, Darmstadt

3 Institut für Diagnostische und Interventionelle Radiologie, Universität Düsseldorf, Düsseldorf

${ }^{4}$ Klinik für Gynäkologie und Geburtshilfe, Markus Krankenhaus, Frankfurt am Main

${ }^{5}$ Katholisches Klinikum Oberhausen, Frauenklinik St. Clemens-Hospital, Oberhausen

${ }^{6}$ Klinik und Poliklinik für Frauenheilkunde und Geburtshilfe der Universität München, Campus Großhadern, München, Munich

7 Dysplasiezentrum in der Frauenarztpraxis Heussweg, Hamburg

8 Frauenklinik Luzerner Kantonsspital, Lucerne, Switzerland

${ }^{9}$ Abteilung Gynäkologie und Geburtshilfe, Kreiskliniken Altötting Burghausen, Altötting

${ }^{10}$ Institut für Pathologie des Universitätsklinikums Leipzig, Leipzig

11 ehem. Universitätsfrauenklinik Maistraße, Munich

12 Klinik und Poliklinik für Frauenheilkunde und Geburtshilfe der Universität Köln, Cologne

${ }^{13}$ Klinik und Poliklinik für Radioonkologie und Strahlentherapie der Universität Köln, Cologne

${ }^{14}$ Universitätsfrauenklinik Erlangen, Erlangen

15 Klinik für Gynäkologie und Zentrum für Beckenbodenerkrankungen, Vivantes Klinikum Neukölln, Berlin

${ }^{16}$ Klinik für Gynäkologie und gynäkologische Onkologie, Universitätsfrauenklinik Mainz, Mainz

17 Klinik und Poliklinik für Gynäkologie, Universitätsklinikum Hamburg-Eppendorf, Hamburg

18 Klinik für Frauenheilkunde und Geburtshilfe des Universitätsklinikums Düsseldorf, Düsseldorf 


\section{References}

1 van Seters $M$, van Beurden $M$, de Craen AJ. Is the assumed natural history of vulvar intraepithelial neoplasia III based on enough evidence? A systematic review of 3322 published patients. Gynecol Oncol 2005; 97: 645-651

2 Stephenson RD, Denehy TR. Rapid spontaneous regression of acute-onset vulvar intraepithelial neoplasia 3 in young women: a case series. J Low Genit Tract Dis 2012; 16: 56-58

3 Fanning J, Lambert HC, Hale TM et al. Paget's disease of the vulva: prevalence of associated vulvar adenocarcinoma, invasive Paget's disease, and recurrence after surgical excision. Am J Obstet Gynecol 1999; 180: $24-27$

4 Lam C, Funaro D. Extramammary Paget's disease: summary of current knowledge. Dermatol Clin 2010; 28: 807-826

5 Funaro D, Krasny M, Lam C et al. Extramammary Paget disease: epidemiology and association to cancer in a Quebec-based population. J Low Genit Tract Dis 2013; 17: 167-174

6 Hampl M, Deckers-Figiel S, Hampl JA et al. New aspects of vulvar cancer: changes in localization and age of onset. Gynecol Oncol 2008; 109: 340-345

7 Chi CC, Kirtschig G, Baldo $M$ et al. Topical interventions for genital lichen sclerosus. Cochrane Database Syst Rev 2011; 12: CD008240

8 Brinton LA, Nasca PC, Mallin K et al. Case-control study of cancer of the vulva. Obstet Gynecol 1990; 75: 859-866

9 Monk BJ, Burger RA, Lin F et al. Prognostic significance of human papillomavirus DNA in vulvar carcinoma. Obstet Gynecol 1995; 85: 709715

10 Madsen BS, Jensen HL, van den Brule AJ et al. Risk factors for invasive squamous cell carcinoma of the vulva and vagina-population-based case-control study in Denmark. Int J Cancer 2008; 122: 2827-2834

11 Kutlubay Z, Engin B, Zara T et al. Anogenital malignancies and premalignancies: facts and controversies. Clin Dermatol 2013; 31: 362-373

12 HPV-Managementforum (HPV-MF); Paul-Ehrlich-Gesellschaft für Chemotherapie e.V. (PEG). S3 Leitlinie - Impfprävention HPV-assoziierter Neoplasien, AWMF Registernummer 082/002. 2013. Online: http:// www.awmf.org/uploads/tx_szleitlinien/082-0021_Impfpr\%C3\%A4 vention_HPV_assoziierter_Neoplasien_2013-12.pdf; last access: 26.03.2016

13 Hampl M, Sarajuuri H, Wentzensen $N$ et al. Effect of human papillomavirus vaccines on vulvar, vaginal, and anal intraepithelial lesions and vulvar cancer. Obstet Gynecol 2006; 108: 1361-1368

14 De Vuyst H, Clifford GM, Nascimento MC et al. Prevalence and type distribution of human papillomavirus in carcinoma and intraepithelial neoplasia of the vulva, vagina and anus: a meta-analysis. Int J Cancer 2009; 124: 1626-1636

15 Insinga RP, Liaw KL, Johnson LG et al. A systematic review of the prevalence and attribution of human papillomavirus types among cervical, vaginal, and vulvar precancers and cancers in the United States. Cancer Epidemiol Biomarkers Prev 2008; 17: 1611-1622

16 Bundesministerium für Gesundheit. Bekanntmachung eines Beschlusses des Gemeinsamen Bundesausschusses über die Änderung der Schutzimpfungs-Richtlinie (SI-RL): Umsetzung STIKO-Empfehlungen August 2014 und Anpassung an die Verordnung zur arbeitsmedizinischen Vorsorge (ArbMedVV). BAnz AT 2015; 3.02.2015 B2

17 Crum CP. Vulvar intraepithelial neoplasia: the concept and its application. Hum Pathol 1982; 13: 187-189

18 Hart WR. Vulvar intraepithelial neoplasia: historical aspects and current status. Int J Gynecol Pathol 2001; 20: 16-30

19 Reyes MC, Cooper K. An update on vulvar intraepithelial neoplasia: terminology and a practical approach to diagnosis. J Clin Pathol 2014; 67; 290-294

20 Crum CP, Herrington CS, McCluggage WG, Regauer S, Wilkinson EJ. Epithelial Tumors of the Vulva. In: Kurman RJ, Carcangiu ML, Herrington $\mathrm{CS}$, Young RH, eds. WHO Classification of Tumours of the female reproductive Tract. Lyon: IARC Press; 2014: 233-242

21 Horn LC, Klostermann K, Hautmann S et al. HPV-associated alterations of the vulva and vagina. Morphology and molecular pathology. Pathologe 2011; 32: 467-475

22 Heller DS. Report of a new ISSVD classification of VIN. J Low Genit Tract Dis 2007; 11: 46-47

23 Sideri M, Jones RW, Wilkinson EJ et al. Squamous vulvar intraepithelial neoplasia: 2004 modified terminology, ISSVD Vulvar Oncology Subcommittee. J Reprod Med 2005; 50: 807-810
24 Wilkinson E, Teixeira M. Tumors of the Vulva. In: Tavassoli F, Devilee P, eds. Pathology and Genetics of Tumors of the Breast and female genital Organs. World Health Organization Classification of Tumour. Lyon: IARC Press; 2003: 313-334

25 Lawrence WD. ADASP recommendations for processing and reporting of lymph node specimens submitted for evaluation of metastatic disease. Virchows Arch 2001; 439: 601-603

26 Hunt JL, Baloch ZW, LiVolsi VA. Sentinel lymph node evaluation for tumor metastasis. Semin Diagn Pathol 2002; 19: 263-277

27 Horn LC, Einenkel J, Hockel $M$ et al. [Recommendations for the handling and oncologic pathology report of lymph node specimens submitted for evaluation of metastatic disease in gynecologic malignancies]. Pathologe 2005; 26: 266-272

28 Woelber L, Eulenburg C, Choschzick $M$ et al. Prognostic role of lymph node metastases in vulvar cancer and implications for adjuvant treatment. Int J Gynecol Cancer 2012; 22: 503-508

29 Tantipalakorn C, Robertson G, Marsden DE et al. Outcome and patterns of recurrence for International Federation of Gynecology and Obstetrics (FIGO) stages I and II squamous cell vulvar cancer. Obstet Gynecol 2009; 113: 895-901

30 Lataifeh I, Nascimento MC, Nicklin JL et al. Patterns of recurrence and disease-free survival in advanced squamous cell carcinoma of the vulva. Gynecol Oncol 2004; 95: 701-705

31 Beller U, Quinn MA, Benedet JL et al. Carcinoma of the vulva. FIGO 26th Annual Report on the Results of Treatment in Gynecological Cancer. Int J Gynaecol Obstet 2006; 95 (Suppl. 1): S7-S27

32 Chan JK, Sugiyama V, Pham H et al. Margin distance and other clinicopathologic prognostic factors in vulvar carcinoma: a multivariate analysis. Gynecol Oncol 2007; 104: 636-641

33 Cheng X, Zang R, Wu X et al. Recurrence patterns and prognostic factors in Chinese patients with squamous cell carcinoma of the vulva treated with primary surgery. Int J Gynecol Cancer 2009; 19: 158-162

34 National Institutes of Health. NIH State-of-the-Science Conference Statement on improving end-of-life care. NIH consensus and state-ofthe-science statements 2004; $21: 1-26$

35 Tan J, Chetty N, Kondalsamy-Chennakesavan $S$ et al. Validation of the FIGO 2009 staging system for carcinoma of the vulva. Int J Gynecol Cancer 2012; 22: 498-502

36 Aragona AM, Cuneo NA, Soderini AH et al. An analysis of reported independent prognostic factors for survival in squamous cell carcinoma of the vulva: is tumor size significance being underrated? Gynecol Oncol 2014; 132: 643-648

37 Hacker NF, Eifel PJ, van der Velden J. Cancer of the vulva. Int J Gynaecol Obstet 2012; 119 (Suppl. 2): S90-S96

38 Oonk MH, Hollema H, de Hullu JA et al. Prediction of lymph node metastases in vulvar cancer: a review. Int J Gynecol Cancer 2006; 16: 963971

39 Raspagliesi F, Hanozet F, Ditto A et al. Clinical and pathological prognostic factors in squamous cell carcinoma of the vulva. Gynecol Oncol 2006; 102: 333-337

40 van der Velden J, van Lindert AC, Lammes FB et al. Extracapsular growth of lymph node metastases in squamous cell carcinoma of the vulva. The impact on recurrence and survival. Cancer 1995; 75: 2885-2890

41 Hyde SE, Valmadre S, Hacker NF et al. Squamous cell carcinoma of the vulva with bulky positive groin nodes-nodal debulking versus full groin dissection prior to radiation therapy. Int J Gynecol Cancer 2007; 17: $154-158$

42 Fons G, Hyde SE, Buist MR et al. Prognostic value of bilateral positive nodes in squamous cell cancer of the vulva. Int J Gynecol Cancer 2009; 19: $1276-1280$

$43 \mathrm{Xu} L \mathrm{~L}$ Luo RZ, Sun XM et al. Prognostic analysis of early-stage squamous cell carcinoma of the vulva. World J Surg Oncol 2013; 11: 20

44 Zanvettor PH, Filho DF, Soares FA et al. Study of biomolecular and clinical prognostic factors in patients with cancer of the vulva undergoing surgical treatment. Int J Gynecol Cancer 2014; 24: 766-772

45 Royal College of Obstetricians and Gynaecologists. Guidelines for the diagnosis and management of vulval carcinoma. British Gynaecological Cancer Society; 2014. Online: http://www.rcog.org.uk/womenshealth/clinical-guidance/vulval-carcinoma-guidelines-diagnosis-andmanagement; last access: February 2015

46 Viswanathan C, Kirschner K, Truong $M$ et al. Multimodality imaging of vulvar cancer: staging, therapeutic response, and complications. AJR Am J Roentgenol 2013; 200: 1387-1400 
47 Land R, Herod J, Moskovic E et al. Routine computerized tomography scanning, groin ultrasound with or without fine needle aspiration cytology in the surgical management of primary squamous cell carcinoma of the vulva. Int J Gynecol Cancer 2006; 16: 312-317

48 de Gregorio N, Ebner F, Schwentner L et al. The role of preoperative ultrasound evaluation of inguinal lymph nodes in patients with vulvar malignancy. Gynecol Oncol 2013; 131: 113-117

49 Abang Mohammed DK, Uberoi R, de BLA et al. Inguinal node status by ultrasound in vulva cancer. Gynecol Oncol 2000; 77: 93-96

50 Cohn DE, Dehdashti F, Gibb RK et al. Prospective evaluation of positron emission tomography for the detection of groin node metastases from vulvar cancer. Gynecol Oncol 2002; 85: 179-184

51 Kataoka MY, Sala E, Baldwin P et al. The accuracy of magnetic resonance imaging in staging of vulvar cancer: a retrospective multi-centre study. Gynecol Oncol 2010; 117: 82-87

52 Bipat S, Fransen GA, Spijkerboer AM et al. Is there a role for magnetic resonance imaging in the evaluation of inguinal lymph node metastases in patients with vulva carcinoma? Gynecol Oncol 2006; 103: 10011006

53 Sohaib SA, Richards PS, Ind T et al. MR imaging of carcinoma of the vulva. AJR Am J Roentgenol 2002; 178: 373-377

54 Hawnaur JM, Reynolds $K$, Wilson $G$ et al. Identification of inguinal lymph node metastases from vulval carcinoma by magnetic resonance imaging: an initial report. Clin Radiol 2002; 57: 995-1000

55 Singh K, Orakwue CO, Honest $H$ et al. Accuracy of magnetic resonance imaging of inguinofemoral lymph nodes in vulval cancer. Int J Gynecol Cancer 2006; 16: 1179-1183

56 Pecorelli S. Revised FIGO staging for carcinoma of the vulva, cervix, and endometrium. Int J Gynaecol Obstet 2009; 105: 103-104

57 Wittekind C, Meyer H. UICC TNM Klassifikation maligner Tumoren. Weinheim: Wiley-Blackwell; 2010

58 Gentile M, Bianchi P, Sesti F et al. Adjuvant topical treatment with imiquimod 5\% after excisional surgery for VIN 2/3. Eur Rev Med Pharmacol Sci 2014; 18: 2949-2952

59 van Seters $M$, van Beurden $M$, ten Kate FJ et al. Treatment of vulvar intraepithelial neoplasia with topical imiquimod. N Engl J Med 2008; 358: $1465-1473$

60 Mahto M, Nathan M, O'Mahony C. More than a decade on: review of the use of imiquimod in lower anogenital intraepithelial neoplasia. Int J STD AIDS 2010; 21: 8-16

61 Pepas L, Kaushik S, Bryant A et al. Medical interventions for high grade vulval intraepithelial neoplasia. Cochrane Database Syst Rev 2011; 4: CD007924

62 Terlou A, van Seters M, Ewing PC et al. Treatment of vulvar intraepithelial neoplasia with topical imiquimod: seven years median follow-up of a randomized clinical trial. Gynecol Oncol 2011; 121: 157-162

63 Frega A, Sesti F, Sopracordevole F et al. Imiquimod 5\% cream versus cold knife excision for treatment of VIN 2/3: a five-year follow-up. Eur Rev Med Pharmacol Sci 2013; 17: 936-940

64 Hockel M, Dornhofer N. Anatomical reconstruction after vulvectomy. Obstet Gynecol 2004; 103: 1125-1128

65 Gaarenstroom KN, Kenter GG, Trimbos JB et al. Postoperative complications after vulvectomy and inguinofemoral lymphadenectomy using separate groin incisions. Int J Gynecol Cancer 2003; 13: 522-527

66 Hinten F, van den Einden LC, Hendriks JC et al. Risk factors for short- and long-term complications after groin surgery in vulvar cancer. $\mathrm{Br}$ J Cancer 2011; 105: 1279-1287

67 Soliman AA, Heubner M, Kimmig $R$ et al. Morbidity of inguinofemoral lymphadenectomy in vulval cancer. ScientificWorldjournal 2012; 2012: 341253

68 Benedet JL, Turko M, Fairey RN et al. Squamous carcinoma of the vulva: results of treatment, 1938 to 1976. Am J Obstet Gynecol 1979; 134: 201-207

69 Hopkins MP, Reid GC, Vettrano I et al. Squamous cell carcinoma of the vulva: prognostic factors influencing survival. Gynecol Oncol 1991; 43: $113-117$

70 Lin JY, DuBeshter B, Angel C et al. Morbidity and recurrence with modifications of radical vulvectomy and groin dissection. Gynecol Oncol 1992; 47: 80-86
71 Klemm P, Marnitz S, Kohler C et al. Clinical implication of laparoscopic pelvic lymphadenectomy in patients with vulvar cancer and positive groin nodes. Gynecol Oncol 2005; 99: 101-105

72 Shylasree TS, Bryant A, Howells RE. Chemoradiation for advanced primary vulval cancer. Cochrane Database Syst Rev 2011; 4: CD003752

73 Geisler JP, Manahan KJ, Buller RE. Neoadjuvant chemotherapy in vulvar cancer: avoiding primary exenteration. Gynecol Oncol 2006; 100: 5357

74 Oonk MH, de Hullu JA, Hollema $\mathrm{H}$ et al. The value of routine follow-up in patients treated for carcinoma of the vulva. Cancer 2003; 98: 26242629

75 Oonk MH, van Hemel BM, Hollema H et al. Size of sentinel-node metastasis and chances of non-sentinel-node involvement and survival in early stage vulvar cancer: results from GROINSS-V, a multicentre observational study. Lancet Oncol 2010; 11: 646-652

76 Woelber L, Grimm D, Vettorazzi E et al. Secondary sentinel node biopsy after previous excision of the primary tumor in squamous cell carcinoma of the vulva. Ann Surg Oncol 2013; 20: 1701-1706

77 Van der Zee AG, Oonk MH, De Hullu JA et al. Sentinel node dissection is safe in the treatment of early-stage vulvar cancer. J Clin Oncol 2008; 26: 884-889

78 Maggino T, Landoni F, Sartori E et al. Patterns of recurrence in patients with squamous cell carcinoma of the vulva. A multicenter CTF Study. Cancer 2000; 89: 116-122

79 Woolderink JM, de Bock GH, de Hullu JA et al. Patterns and frequency of recurrences of squamous cell carcinoma of the vulva. Gynecol Oncol 2006; 103: 293-299

80 Regauer $S$. Residual anogenital lichen sclerosus after cancer surgery has a high risk for recurrence: a clinicopathological study of 75 women. Gynecol Oncol 2011; 123: 289-294

81 Gordinier ME, Malpica A, Burke TW et al. Groin recurrence in patients with vulvar cancer with negative nodes on superficial inguinal lymphadenectomy. Gynecol Oncol 2003; 90: 625-628

82 Cormio G, Loizzi V, Carriero C et al. Groin recurrence in carcinoma of the vulva: management and outcome. Eur J Cancer Care (Engl) 2010; 19: 302-307

83 de Hullu JA, Hollema H, Lolkema S et al. Vulvar carcinoma. The price of less radical surgery. Cancer 2002; 95: 2331-2338

84 Hassanzade M, Attaran M, Treglia G et al. Lymphatic mapping and sentinel node biopsy in squamous cell carcinoma of the vulva: systematic review and meta-analysis of the literature. Gynecol Oncol 2013; 130: 237-245

85 Coulter J, Gleeson N. Local and regional recurrence of vulval cancer: management dilemmas. Best Pract Res Clin Obstet Gynaecol 2003; 17 : 663-681

86 Husain A, Akhurst T, Larson S et al. A prospective study of the accuracy of 18Fluorodeoxyglucose positron emission tomography (18FDG PET) in identifying sites of metastasis prior to pelvic exenteration. Gynecol Oncol 2007; 106: 177-180

87 Hopkins MP, Morley GW. Pelvic exenteration for the treatment of vulvar cancer. Cancer 1992; 70: 2835-2838

88 Hoffman MS, Cavanagh D, Roberts WS et al. Ultraradical surgery for advanced carcinoma of the vulva: an update. Int J Gynecol Cancer 1993; 3: $369-372$

89 Chiantera $V$, Rossi M, De Iaco P et al. Morbidity after pelvic exenteration for gynecological malignancies: a retrospective multicentric study of 230 patients. Int J Gynecol Cancer 2014; 24: 156-164

90 Miller B, Morris M, Levenback C et al. Pelvic exenteration for primary and recurrent vulvar cancer. Gynecol Oncol 1995; 58: 202-205

91 Weikel W, Schmidt M, Steiner E et al. Surgical therapy of recurrent vulvar cancer. Am J Obstet Gynecol 2006; 195: 1293-1302

92 Salom EM, Penalver M. Recurrent vulvar cancer. Curr Treat Options Oncol 2002; 3: 143-153

93 Hruby G, MacLeod C, Firth I. Radiation treatment in recurrent squamous cell cancer of the vulva. Int J Radiat Oncol Biol Phys 2000; 46: 1193-1197 
Guideline Program

\section{Editors}

Leading Professional Medical Associations

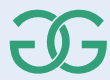

German Society of Gynecology and Obstetrics (Deutsche Gesellschaft für Gynäkologie und Geburtshilfe e. V. [DGGG])

Head Office of DGGG and Professional Societies Hausvogteiplatz 12

DE-10117 Berlin

info@dggg.de

http://www.dggg.de/

President of DGGG

Prof. Dr. med. Diethelm Wallwiener

Universitätsfrauenklinik Tübingen

Calwerstraße 7

DE-72076 Tübingen

DGGG Guidelines Representative

Prof. Dr. med. Matthias W. Beckmann

Universitätsklinikum Erlangen

Frauenklinik

Universitätsstraße 21-23

DE-91054 Erlangen

\section{Guidelines Coordination}

Dr. med. Paul Gaß, Tobias Brodkorb, Marion Gebhardt

Universitätsklinikum Erlangen

Frauenklinik

Universitätsstraße 21-23

DE-91054 Erlangen

fk-dggg-leitlinien@uk-erlangen.de

http://www.dggg.de/leitlinienstellungnahmen

\section{OEGGG}

Austrian Society of Gynecology and Obstetrics (Österreichische Gesellschaft für Gynäkologie und Geburtshilfe [OEGGG])

Innrain 66A

AT-6020 Innsbruck

stephanie.leutgeb@oeggg.at

http://www.oeggg.at

\section{President of OEGGG}

Prof. Dr. med. Uwe Lang

Universitätsklinik für Frauenheilkunde und Geburtshilfe Graz

Auenbruggerplatz 14

AT-8036 Graz

OEGGG Guidelines Representative

Prof. Dr. med. Karl Tamussino

Universitätsklinik für Frauenheilkunde

und Geburtshilfe Graz

Auenbruggerplatz 14

AT-8036 Graz

\section{gynécologie}

$$
\text { suisse }
$$

Swiss Society of Gynecology and Obstetrics (Schweizerische Gesellschaft für Gynäkologie und Geburtshilfe [SGGG])

Gynécologie Suisse SGGG

Altenbergstraße 29

Postfach 6

CH-3000 Bern 8

sekretariat@sggg.ch

http://www.sggg.ch/

President of SGGG

Dr. med. David Ehm

FMH für Geburtshilfe und Gynäkologie

Nägeligasse 13

CH-3011 Bern

\section{SGGG Guidelines Representative}

Prof. Dr. med. Daniel Surbek

Universitätsklinik für Frauenheilkunde

Geburtshilfe und feto-maternale Medizin

Inselspital Bern

Effingerstraße 102

$\mathrm{CH}-3010$ Bern 